\title{
EUROPEAN POLICY AS ADAPTIVE BEHAVIOR OF GERMANY AND THE LEADERSHIP ROLE IN EU AS A RESULT OF POLITICAL ADAPTATION
}

Sylwia ZAWADZKA, PhD candidate

University of Wroclaw, Social Sciences Department, Poland sylwia.zawadzka@uwr.edu.pl

\begin{abstract}
The European Union has been gradually transforming in the process of progressive integration. An example of the serious implications of these changes were multiple crises that called the European order into question, thus posing a challenge to keep the essential structures of the EU within acceptable limits. The crises have forced EU decision-makers and Member State governments to adopt appropriate adaptive behavior by implementing correct response mechanisms. Adaptation to change has become the foundation of the European policies of the Member States. The author uses the theory of political adaptation to analyze German European policy. Initially, its main determinants were presented in the context of shaping adaptive behavior. Then, based on them, the model of adaptation to changes in the EU preferred by the German authorities was formulated. Using the comparative method and case study, the adaptation model in the situation of minimal changes in Germany and the EU compared with the form of adaptive behavior in it might be rapid changes caused by the Eurozone crisis and the refugee crisis. They were the main catalyst for the reformulation of Germany's adaptive approach from 'habitual' to 'deliberative' or 'convulsive' which resulted in strengthening the role of the leader.
\end{abstract}

Keywords: political adaptation, leadership, crisis, Germany.

\section{Introduction}

Political processes occurring in the international system and related to the opportunities and threats to the development of states become determinants of foreign policy, which includes the interaction between the entity adapting to change and the external environment in which it occurs. Activities related to the implementation of foreign policy in all its dimensions can be considered as adaptive behavior. Such a research approach requires building the analytical framework of the problem, explaining the theory, and verifying hypotheses using specified 
methods. The adaptive perspective in the present article has been reduced to exploring a part of political reality related to Germany's European policy and the role of this country in the EU in a situation of rapid changes. In the author's assumption, there is a clear gap in scientific discourse concerning treating political adaptation as a research approach and using it for practical analysis of processes and phenomena occurring in international relations. The article provides an attempt to transfer the adaptation perspective to the level of German European policy as one of the key dimensions of foreign policy. In contrast, government actions in relation to attempts to solve crises, according to the adopted assumption, are treated as the effect and the main manifestation of political adaptation.

Following the accepted methodological framework of research, the purpose of the article is to define the main determinants of German European policy in the context of adaptive behavior and to create on its basis a model of adaptation to changes occurring in the EU. The use of the theory of political adaptation required clarifying the general priorities of German European policy after reunification. However, the most important aspect of the analysed adaptive behavior was the government's response to rapid external changes caused by the Eurozone crisis and the refugee crisis. In this aspect, it was essential to clarify to what extent Germany's European leadership, especially in the periods of crises being analysed, can be described as the result of the political adaptation process. The author formulated several hypotheses. First of all, the German adaptation model is understood as the type/mode of adaptive behavior changes depending on the analysed political phenomena. Secondly, Germany can be seen as the political 'homeostat' of the EU system maintaining its internal balance. Finally, last but not least, political adaptation to the role of leader was effective in the Eurozone crisis, while in the case of the refugee crisis, implemented adaptation solutions led to internal changes, which hinders the positive assessment of this process. Comparison of adaptive models in slight and significant changes required the use of the comparative method. In turn, the case-study approach complemented comparative research and allowed to determine Germany's adaptability in various contexts.

The article was organised into three parts. The first describes the theory of political adaptation and explains the possibilities of using this model as a research approach in political science. The second part explains the main postulates recognizing European policy as a platform for adaptive behavior. On this basis, the main parameters of German European policy were defined to determine the adaptive behavior model. In the last part, attention has been focused on explaining 
the phenomenon of German leadership in the EU as an implication of adaptation to changes caused by crises, taking into account individual adaptation models. Finally, a comparative analysis of the strategy of German's political adaptation in the EU during the Eurozone crisis and the refugee crisis was presented. According to the central claim of the research, these phenomena contributed to the change in the adaptive environment, in which Germany played the leading role, adapting to the role of leader.

\section{Adaptation as a political process}

Adaptation as an interdisciplinary concept has become an object of analysis in both natural and social sciences. It can be a valuable category for explaining phenomena and processes from various cognitive perspectives. Therefore, when trying to embed the concept of adaptation in the appropriate definition framework, it is important to rely on examples specific to a given discipline and transfer the theoretical model to the problems analyzed there. Although some research approaches center the debate on adaptation as the consequences of environmental changes, it should be seen not as a result or state but primarily as a process - more or less dynamic (Mayr, 1982, p. 483). Its essence is to adapt the organism to new conditions. The effectiveness of adaptation can only be tested in the long-term perspective, by observing the response of the environment and internal structures (Simonet, 2010, p. 4; Bates 2005).

In socio-psychological analyses, adaptation is understood as a process of unremitting interaction between the individual and the dynamically changing world in which it operates. On the one hand, this complex dynamics refers to the change in the behavior of the adaptive entity, and on the other - to processes that determine the emergence of transformation perspectives (Jakubowicz, 2002, pp. 247-250). The change in the entity's operating strategy results from processing information from the environment, allowing it to decide to adapt to new conditions. The subject's effectiveness in responding to new situations depends on the ability to modify behavior or its structure (Taché, 2003, p. 362; Simonet, 2010, pp. 4-6).

The concept of adaptation can also analyze political processes, especially in shaping specific foreign policy strategies by decision-making centers. J. N. Rosenau, who initiated research on adaptive behavior in this dimension, defined adaptation as an action aiming at preserving and protecting social structures and attributes of the state constituting its essence (Rosenau, 1981, pp. 3-5). The direct determinants of adaptation processes are the behavior of decision-makers and the 
nature of decisions regarding individual dimensions of foreign policy. Political adaptation is initiated internationally when there are mechanisms of mutual influence between states, accompanied by constant changes in the internal and external environment. Their scale, intensity, and pace are different. The entity, adapting to specific conditions, operates with different strategies, to adapt to changes and adaptability.

According to the theory of political adaptation understood as a dynamic process, decisions in the sphere of foreign policy can be seen as adaptive behavior if they are an adequate response to changes in the external environment of the state and support the maintenance of its essential structures within acceptable limits, which in turn are determined by decision-makers and society (Rosenau, 1970, p. 367). If the changes occurring in the internal and external environment are minimal, then also the government's actions are oriented towards the minimum degree of adaptation by using the available tools of current policy. Another situation occurs when the internal or/and external environment is subject to rapid changes that may pose a potential threat to essential social, economic, and political structures. Existing procedures of current policy may transpire unreliable and inadequate to the changes. Their continuation could mean passivity in practice. The adaptation strategy must, therefore, take account of decided ad hoc behavior.

To sum up, political adaptation to the environment in a regional or international dimension depends on the state's needs and capabilities as well as conditions and absorption capacity of the environment. In turn, changes in the external environment force a change in adaptive behavior by adopting a different strategy for conducting foreign policy or making ad hoc decisions that are to be an adequate response to changes. Often, the adaptive behavior of the state is the result of the expectations of the external environment to assume greater responsibility for situations in surroundings. Especially when the state plays a key role in the regional (regional power) or global system (global power). The main issue to be resolved is the degree of the state's influence on shaping the external environment and strengthening the balance by stimulating occurred their changes, as well as the degree of the impact of the environment on intra-state transformations.

\section{European Policy as an Adaptive Behavior}

\subsection{Changes and models of adaptation}

According to the theory of J. N. Rosenau, the environment in which the organism functions is constantly changing, which in turn hinders its development and even threatens its survival 
(Rosenau, 1970, p. 365). The natural consequence of changes is an attempt to adapt to new conditions by implementing an appropriate adaptation strategy. The state that functions in a dynamically changing international environment, which can be understood as the physical limitations of the activities of the political units that make up the international system, is subject to the same processes (Waltz, 1976, pp. 40-41). According to the assumptions of the adaptation perspective, the state does not have to adapt to all changes that take place outside its borders. It must adapt to those (within the international system) that are relevant to its essential structures. In this way, his significant adaptation environment is marked (Rosenau, 1970, pp. 371-372). The survival of the state depends on its adaptability as well as the influence of other entities and the absorption capacity of the system in which it participates. Considering the existence of interactions between the environment and the state and its internal attributes, two dimensions of the functioning of the state should be taken into account: the environment of its activity and the possibility of adaptation to a dynamically changing environment (Rosenau, 1970, pp. 366). Political adaptation involves not only activities aimed at maintaining social structures and key elements of statehood but also using the potential of the environment by influencing its shape. It is a process that strengthens and develops the state's capacity for political influence on the regional and global scale.

The absorption possibilities of the environment, which creates a multidimensional system of connections and interrelationships between states and other international relations subjects, are expressed through the ability to recognize the value of knowledge derived from external sources, its assimilation, and application (Cohen and Levinthal, 1990). In the case of the European Union, these capabilities relate primarily to the policy of expanding structures by the new Member States joining (Emerson, Aydin, Clerck-Sachsse and Noutcheva, 2006) and the adaptation to EU policies in specific areas (e.g., adaptation to climate change; adaptation health and social policy). However, following the definition of Cohen and Levinthal, should also be added the ability to recognize the preferences of entities adapting to the role of Member States, as well as fully-fledged members, which each time - as a result of changes in the EU (also in the sequel absorption of new entities) - redefine the priorities of theirs activity. Preferences as derivatives of state interests are contained in foreign policy strategies and (in the EU environment) - European policy strategy as one of its dimensions. However, the effectiveness of adaptation depends on the realisation of goals. 
The category that helps explain the adaptation process and the relationship between the state and its significant environment is the concept of change, which, according to R. Gilpin, can occur at three levels of the system and applies primarily to states. The first level provides an overall change in a coherent system by changing the elements determining its integrity. The second level is the systemic change within the control or management of the political system. In the third approach, changes occur in the interaction of entities maintaining relationships in the international system. (Gilpin, 1984, pp. 39-44). Gilpin also analysed the relationship between state action focused on introducing these changes and the stability of the environment in which they operate. According to his concept, countries make efforts to transform the international system if the benefits outweigh the costs resulting from rational calculation. Furthermore, Dopson and Neumann perceived change as an evil necessary to survive in a situation of uncertainty (Dopson and Neumann 1998, pp. 53-70; Alas and Gao 2012, p. 74).

The category of change was also the subject of Rosenau's research, which made the type of foreign policy and adaptation dependent on transformations taking place in the external and internal environment of the adaptive state. To internal changes, which do not affect an express change in the adaptive behavior of the state, he included such personal changes in state leadership positions that do not undermine the political continuity of the established principles. However, internal changes, which break with the current social, economic, and political order (e.g., change of political regime, the electoral victory of a new party), he considered changes important for adaptive behavior. The same principle applies to the external environment. The impulse to initiate the adaptation process is political and socio-economic changes in the significant environment of the state (Rosenau, 1970, pp. 372-377).

Due to the degree of intensity of external and internal changes, he distinguished four models: habitual, deliberative, spirited, and convulsive (Rosenau, 1970, pp. 378-380). Implementing a habitual adaptation model is possible when in both internal and external environments, slight changes that do not force political decision-makers to urgency redefine activities. The state can function in an international environment following the chosen strategy of its activity and established procedures corresponding to current policy. The deliberative policy model is preferred when there are rapid changes in the external environment and minimal (or no changes) in the internal system. In the absence of domestic demands, the state may focus on developing tools that are a prudent response to changes in the international environment because 
the current procedures in a situation of rapid external changes will not be sufficient. However, the spirited adaptation model occurs when there are significant changes in the internal environment, while the external one is relatively stable. The fourth model - convulsive policy as an adaptation strategy is determined by high changes in both environments (Rosenau, 1970, pp. 378-380). Then, the national decision-making centers must not only take action in response to internal pressures and social demands but also meet the expectations of a rapidly changing external environment. Expectations and pressure exerted from outside may depend on the position of a country in regional or global structures. Current strategies lose credibility in the face of internal and external changes, which force the need to take new, decisive actions. Effective recognition of changes and their management by creating appropriate adaptation strategies can contribute to crisis prevention. Changes in the environment can also help strengthen the country, which should be considered the highest adaptation level.

Rosenau also took into account the country's potential and adaptability in shaping foreign policy strategies. On this basis, he created a second division and distinguished four types of political adaptation: (1) preservative oriented to maintain the balance between the internal and external environment; (2) acquiescent, which implies changes in internal structures due to external pressures; (3) intransigent, consisting in ignoring the influence of the international environment on national politics; (4) promotive, which is expressed by strengthening cooperation with the external environment (Rosenau, 1987). This division fulfils only a complementary function due to treating the changes as a focal point of research.

\subsection{The German European policy in the significant environment of adaptation}

The theory of adaptation may apply to the analysis of European policy as one of the dimensions of foreign policy. However, before analysing the main parameters of German European policy (Europapolitik) in the context of the adaptive behavior model, the specificity of the EU environment should be clarified, taking into account the changes that resulted in the improvement or deterioration of the state of internal equilibrium. Firstly, what should be emphasized, two adaptation processes occur in the EU due to the type of entity that is being adapted. The first refers to candidate countries (or potential candidates) for membership. According to Article 49 of TEU, any European country can join the Union if it respects common values and undertakes to support them. Enlargement policy is one of the most effective tools to 
support political, social, and economic reforms in countries that need to adapt to the EU model by requiring specific criteria to be met. The consequence of this is the gradual Europeanisation of national political systems. The second type of adaptation refers to the Member States which, operating within the EU structures, must adapt to changes taking place within the Community. Changes caused by internal or external factors have an impact on the role and position of Member States, the need to develop a new approach to foreign policy, and even internal policy if they force changes to the previously preferred procedures. The European Union, treated as a significant external environment of a country adapting to intergovernmental and supranational organizational structures, affects its internal potential and international position. Due to the scope of research, the adaptation model of the Member State was analysed, which at the same time became a founder member of the Community structures, and therefore played an essential role in shaping integration processes.

The EU political system is marked by a specificity that cannot be attributed to any other political unit. It forces the Member States to operate in intergovernmental and supranational structural conditions. However, the goal of each system is to survive by maintaining a balance between the internal state and the state of the environment. This phenomenon was defined by $\mathrm{W}$. B. Cannon as the idea of homeostasis, which according to his theory 'does not mean something fixed and immovable, stagnation. It means a condition that may vary but is relatively constant (Cannon 1932, pp. 177-201). To reduce the vulnerability of the system to interference, it is necessary to have a specific homeostat, i.e., the element responsible for maintaining this balance. In the theory of political realism, great powers play the role of the controlling subsystems in the international system. They create complex relationships depending on the distribution of power between them (Waltz 1969, 343).

The fount of power in the EU is both top-down Community decisions and solutions adopted as a result of intergovernmental agreements, which means that final decisions are influenced primarily by EU countries and institutions that use the powers delegated to them by state decisionmaking centers. The implementation of Community tasks depends largely on national political will (Giddens, 2009, p. 202). Similarly, the EU has an impact on the political system of the Member States (their institutions, legal system, administration, etc.). The environment of interactions between the components of the EU system results from the clash of different integration concepts and conflicting national interests. 
Throughout the political evolution of EU structures, Germany was one of the main driving forces of the united Europe project. Its membership in the EU not only strengthens its ability to act on a global scale. A manifestation of Germany's political adaptation within the EU is the use of its position to shape the environment and policies of the EU. The issue to be resolved is to what extent this country can be seen as the political homeostat of the EU system.

Although many decisions taken by the governments of Member States seem to be ad hoc actions regarding current transformations, those are an expression of a broader strategy that is the main carrier of adaptive behavior of Member States. Therefore, to explain this process, firstly should be discussed the main (in the author's opinion - the most important from the perspective of the adopted theory) determinants of German European policy, which is defined as the policy conducted towards the EU (Rittershofer, 2007, p. 230) to influence the direction and scope of European integration (Schmidt, 1995, p. 286), and this is the main tool of political adaptation. The realiszation of the research purpose does not require an analyzis of the priorities of the integration doctrine before the reunification of Germany, because until 1990 - East Germany being under the influence of the USSR, did not participate in the formation and implementation of the concept of unification of Western Europe (Wüstenhagen, 2004, p. 495-509). The process of German emancipation in foreign policy began after gaining full sovereignty in the international arena. Germany's new approach to European integration based on the priorities of expanding structures with new countries, deepening cooperation, and successive reforms of the European Community and later the EU has also been shaped. Germany's European policy is characterized by the conceptional continuity of the ruling party and relatively constant priorities. Even significant internal changes on the German political scene in 1998, which initiated the rule of Chancellor G. Schröder (who run for office on behalf of the Social Democratic Party of Germany - SPD), did not break with the vision of European integration of H. Kohl and the concept of European policy.

Similarly to the governments of the Christian Democratic Union of Germany (CDU), Christian Social Union in Bavaria (CSU), and Free Democratic Party (FDP) - the coalition of SPD and the Alliance 90/The Greens has recognized issues such as: further deepening of cooperation between Member States; EU enlargement to include Central and Eastern European countries; development of political union; strengthening the European Parliament; further development of the CFSP - as European policy priorities (Koalitionsvereinbarung, 1998, pp. 38-45). The change in the ruling coalition, which seems to be a significant internal change, did not affect the radical 
change in adaptive behavior. After the assumption of the Chancellor post by A. Merkel in 2005, the tradition of strengthening European integration was maintained, and Germany assumed even greater responsibility for European affairs.

After the reunification of Germany in 1990, the focus was on unifying the continent through European integration, which has firmly anchored in the value system of Germany. Process of integration required reconciliation with Poland, and the development of economic cooperation with Central and Eastern Europe after the Dissolution of the USSR. The reconciliation policy through integration, Europeanisation of the unification policy, and adaptation to the civilian force model have become the leading ideas of German European policy (Böttger and Jopp 2017, p. 5). Germany was primarily focused on deepening economic integration by shaping the single market and the Economic and Monetary Union in line with the principles of ordoliberalism. Impact on the development of the monetary policy in the euro area in line with the German financial model; political pressure on the independence of the European Central Bank (in imitation of Deutsche Bundesbank) and equipping it with the competence to maintain price stability and control the responsibility of Member States have become one of the elements of the German model of political adaptation in the EU. It can be said that the goal of European 'supranationality' and the vision of structuring Europe according to federal principles and respecting the principles of subsidiarity were present in the German vision of integration during the reunification, but also later, as evidenced by the postulates of the German government relating to adoption the Constitutional Treaty, and then of the Treaty of Lisbon (Böttger and Jopp 2017, pp. 5-6).

Another determinant of Germany's European policy was the Europeanisation of the national interest, which means identifying it with the European interest. Germany's activities are rooted in the EU in many policy areas (Wessels, 1997, pp. 267-299). Adaptation to the changes caused by the introduction of new treaties was characterized by a strong bond between German and European policies. An example of this is the EU competition policy, which forced Germany to adapt its solutions to the principles introduced by the European Commission, or asylum and migration policy, which became Germany's political priority, especially in the era of the refugee crisis (Böttger and Jopp, 2017).

Apart from Europeanisation, an equally important element of German adaptation by European policy is the process of shaping its regional environment. The structure, single market rules, and competition system were examples of transferring German interests to the EU level. 
German preferences for the democratization of the European law-making process were used to strengthen the legislative powers of the European Parliament by introducing the codecision procedure in line with the Maastricht Treaty and then the ordinary legislative procedure established by the Treaty of Lisbon. Besides, as has already been mentioned, the architecture of the monetary union and the structure of the European Central Bank also correspond to German preferences. Adaptation to the EU by influencing the shape of its political system is also observable in the CFSP. Germany was involved in the process of strengthening political integration by unifying this policy area. The combination of the position of the EU High Representative for CFSP with the function of the Vice-President of the European Commission was in line with German preferences (Gaedtke, 2009, pp. 31-41).

The German political discourse regarding the vision of European integration and the attitude towards the CFSP was dominated by the federalist concept, according to which it is necessary to create supranational community mechanisms. In implementing this approach, the German government, despite serious reservations by the supporters of the EU's intergovernmental nature, pushed for accession to work on the Lisbon Treaty based on the previously rejected Constitutional Treaty. It should be noted, however, that an important strategy for Germany's actions in the aspect of shaping the EU's political system and the vision for the development of the CFSP is multilateralism, according to which a more preferred way of initiating specific undertakings is cooperation, especially with France, as Germany's main partner within the EU. After reunification, the 'hard core' concept was also developed, presented in 1994 by W. Schäuble, K. A. Lamers, and T. Waigel. It would include the strongest EU countries capable of reforming it and deepening integration. In turn, peripheral countries were to adapt to these assumptions (Koenig, 2014, p. 1). In recent years, this concept has been attributed to French foreign policy, as evidenced by the overtone of the French President's Manifesto to Europeans, in which he presented his vision of Europe (Macron, 2019). As a result of the deepening political split, Germany maintains its position of strengthening EU cohesion and balance, opposing French demands for greater centralization (Kramp-Karrenbauer, 2019). However, the alliance with France remains a key determinant of European policy-making, as confirmed in 2018 in the Meseberg Declaration and the Aachen Treaty of 2019.

The German strategy of European policy is inspired by values widely recognized as European values. Initially, the key aspect of integration was reconciliation, an attempt to rebuild 
the trust of European partners. With time, the promotion of democracy and stability in Europe was also added to this, which was an expression of Germany's European responsibility. Hence the manifestation of the adaptation model to changes in the EU was support for Enlargement policy in Southern and then in Eastern Dimension to strengthen democracy in these countries (Becker, 2011). Support for Enlargement policy was confirmed by the speech of Chancellor A. Merkel before the establishment of the Lisbon Treaty: 'Strong Germany is not an end in itself. Germany's goal is to be a reliable partner for its friends in Europe and the world. We want to be actively involved in promoting peace, sustainable development, prosperity and justice in the world (...) We see ourselves as a mediator in Europe, and we are particularly interested in supporting and promoting the interests of smaller Member States' (Merkel, 2006).

In addition, the argument that European integration is rooted in the German value system is their attachment to the common currency. This approach was demonstrated by the government of Chancellor A. Merkel in response to the Eurozone crisis. According to the head of the federal government, the collapse of the euro would cause the collapse of Europe (Merkel, 2010). It was a continuation of H. Kohl's vision of a common currency to guarantee stability and peace in Europe (Keßler, 2010, pp. 119-171). Germany's efforts to strengthen the rule of law in the EU, initiated jointly with France to guarantee tools (early warning mechanisms) in the event of a breach by one of the Member States of the fundamental values laid down in the original acquis Communautaire, are also important (COM/2014/158 final).

By adjusting the adaptive behavior model to the European policy pursued, external changes should be considered the most important determinants of this process in Germany. The internal environment in determining European policy priorities and goals after reunification was relatively stable. The above arguments and analysis of adaptive behavior concerning activities related to the deepening of European integration require the formulation of preliminary conclusions: political adaptation was adjusted primarily to external changes and fluctuated between a habitual and deliberative model (assuming minimal changes in the internal environment), depending on from the stage of European integration, and more or less dynamic changes in the EU. The second part of the analysis has been shown what model of adaptation in crises German decision-makers chose and what consequences it had for Germany's position and maintaining a stable situation in the EU. 


\section{Adaptation to the role of leader as an implication of the crisis}

An entity, by adapting to a relevant environment, is influenced by it. The consequence of this may be a change in its position in the international system. Trying to meet the environment's expectations, assumes greater responsibility for solving problems important for the whole environment. Depending on the situation, adopting a specific role may be an initiative of the state or imposed from outside. The key problem that is the starting point for analysing the role of an entity in a given system of interdependence is whether it is able to obtain certain benefits as a result of this process and to what extent it must be responsible for subsequent changes occurring in a relevant system. Therefore, leadership can be seen as a political process in which a given entity tries to direct the activities of a group of entities and influence decisions, by 'providing solutions to problems, offering ideas to achieve common goals' (Keohane, 2012, p. 19). The concept of leadership is not the same as the concept of power (Aggestam and Hyde-Price, 2019, p. 4). The state can be a leader when the power, resources, and abilities are used with maximum effect on the international scene (Stoessinger, 1991, p. 34). Their use, in turn, depends on adaptability and effective response to changes in a significant environment.

The shape of Germany's policy towards the European Union was significantly influenced by crises and their implications. The Eurozone crisis mentioned above, the refugee crisis, but also the crisis of European integration, which was manifested in the implementation of Great Britain's decision to withdraw from the EU structures, irreversibly changed the environment of Member States functioning and forced adaptation to new socio-cultural, economic and political conditions. In such a situation, a leader is needed whose potential and adaptation abilities can guarantee restabilization.

The phenomenon of crisis as a process of a sudden collapse of existing rules can be defined by three key factors: threat, uncertainty, and urgency (Boin and 't Hart, 2006, p. 43). The occurrence of the situation characterized by these elements causes the anxiety of society and their decision-makers. There is a need to search for a specific strategic behavior model and rapid response (Boin and 't Hart, 2006, p. 43). There is a growing expectation of long-term, coordinated actions that will allow to adapt to the new situation and regain control over the system - restore its balance. This expectation is most often directed to the entity with the financial resources, political and military potential. Therefore, it can act as a controlling subsystem (homeostat). Germany is one of the most economically developed countries in the world. According to World Bank data, 
they are in fourth place in terms of GDP (World Bank, 2019, p. 1). They are also one of the largest countries in Europe. They can mobilise other Member States to achieve specific goals or to direct changes in the EU in the desired direction.

The issue of Germany's informal leadership in the EU has become the subject of many scientific studies. In one of them, T. G. Ash emphasized that after reunification Germany became a leader in a politically and economically divided Europe, regardless of whether it was in line with their priorities or not (Ash, 1993, p. 521). Attempts were made to define the type of German leadership in the EU, to distinguish this issue from the problem of hegemony, and to define policy areas in which Germany can be seen as a leader (Aggestam and Hyde-Price, 2019). In this work, in turn, an attempt was made to analyze Germany's leadership role in the EU, which is considered a result of political adaptation associated with the need to adapt to new conditions caused by crises.

\subsection{Eurozone crisis}

The crisis is a concept that is difficult to describe in a specific caesura because its effects can be felt for many years in different structures and different dimensions. In the event of the Eurozone crisis, the most important German initiatives affecting the shaping of the adaptation model at the stage of financial assistance for Greece and the stage of stabilisation of the euro area by postulating the establishment of legal regulations and strengthening financial discipline were analysed. They can be defined as the reaction and stabilisation stages in 2009-2011. Adaptive behavior is understood here as Germany's reaction to the crisis and an attempt to overcome it by initiating a specific solution while strengthening the role and position of this country - as a result of the complex adaptation process. The purpose of the analysis is not to comprehensively explain the causes that led to the crisis because it goes beyond the substantive framework of the research and is not necessary to verify the initial assumptions.

The global economic crisis, which was manifested in the gradual collapse of the financial system, was initiated in the US by the collapse of the high-risk mortgage market. Part of it was the Eurozone debt crisis, which should be considered one of the biggest challenges for maintaining the cohesion and proper functioning of the EU. The presidency of the EU Council in the second half of 2008 was held by France, which is why President N. Sarkozy took the initiative in crisis management and supported the Dutch proposals to launch a special 'protective umbrella' (aid fund of EUR 300 billion) for EU countries threatened with bankruptcy. Such solutions were opposed 
by Germany, which due to its position, would have to cover a large part of the shares. It was part of a deliberative approach to change in the international environment. The German side has developed its solutions that can be considered significant in terms of shaping the first stage of adaptation (reaction stage), the aim of which was an adequate response to external changes while maintaining internal structures within acceptable limits. Despite French pressure to take international coordinated action, Germany has proposed state intervention as a last resort - when a real crisis in the Eurozone arises. Assistance would then be directed in specific cases, assuming that the goal of external action is to strengthen budgetary discipline, austerity policy, and reduce internal debt (Mistral and Unterwedde, 2010, p. 31; Deubner 2011; Kauffmann and Unterwedde, 2010, pp. 13-14).

In April 2009, the International Monetary Fund confirmed that the crisis could spread to euro area countries, lead to an economic recession and increase unemployment on an unprecedented scale (Schmidt, 2009, pp. 388-397; Enderlein, 2010, pp. 7-12). Rapid changes in the markets of the weaker Member States could destabilize the structures of the entire euro area and thus affect the internal structures of other states. Counteracting these phenomena required the adoption of adequate adaptation solutions in the significant environment of the EMU area. Chancellor A. Merkel initially opposed the provision of financial support to debt-laden Greece in the form of coordinated loans from other euro areas Member States. After the European Council summit in March 2010, it was decided that to quickly get out of the crisis, an assistance package for Greece would be launched. However, according to Germany's demands, it was necessary to develop effective measures to increase budgetary discipline and involve the International Monetary Fund in joint activities. The condition for granting coordinated loans from euro area countries was a rigorous austerity introduced by the Greek government (Kauffmann and Unterwedde, 2010, pp. 13-18). The EUR 110 billion rescue package has been agreed by the finance ministers of the single currency for three years and was conditional on the adoption of austerity laws in Greece. Germany's contribution to the aid was to amount to EUR 22.4 billion (loan guarantees and loans).

As indicated in the analysis of European policy determinants, Germany has always taken action within the EU in close cooperation with France as its main ally. In the event of a financial crisis, there were divergences in the attitudes of both countries. French postulates regarding the stabilisation of the euro area took into account the need to create an 'economic government' for 
the countries of the common currency, which could have extensive coordination competencies. A. Merkel, who advocated close coordination and cooperation of all EU countries, initially refused this solution. The economic government postulated by France might divide the Community into two groups - euro area countries and countries outside its structures, which could have contributed to strengthening the political split. In addition, his competences could damage the independence of the ECB (Koszel, 2013). The change in the German government's strategy took place only in 2011 when subsequent collapse of the banking systems occurred in Ireland and Portugal, and the help of governments did not bring the expected results. Chancellor Merkel decided that anti-crisis meetings should be held first among representatives of the countries of the single currency. Ireland and Portugal received immediate assistance in the form of a rescue package from EU stabilisation mechanisms (Alexander and Hildebrand, 2011).

Germany's subsequent actions in the field of political adaptation to rapid external (socioeconomic) changes caused by the financial crisis included the development of preventive measures that were to prevent further breakdowns on European markets. It was about introducing new anticrisis mechanisms, strengthening the budgetary surveillance procedure, and introducing broader sanctions in the preventive and corrective part of the Stability and Growth Pact. The approach of the federal government and its decisive actions that have become the basis of the EU recovery plan illustrates the phenomenon of the formation of Germany's informal leadership in the EU. During the meeting of representatives of the French and German governments in October 2010 in Deauville, Germany called for treaty changes to be put in place as a framework for the orderly management of future crises. It was established that countries that do not meet the required financial criteria might lose their voting rights in key EU matters. (Franco-German Declaration, 2010).

Germany was also in favor of improving governance in the euro area. To this end, they have developed a draft Competitiveness Pact in cooperation with France. Foresaw Eurozone reforms related to adjusting public pay levels to the level of labor productivity; elimination of indexation of pensions and wages; the introduction of an 'automatic budget brake' to rationalize public finance management; adjusting the retirement age to the demographic conditions of a given country; establishing national crisis management regimes for the banking system (national crisis management regime for banks); providing the constitutional law prudential thresholds limiting the possibility of European debt (European Competitiveness Pact). Although the Pact was not adopted 
in the form proposed by the German and French governments due to the opposition of both Member States and supranational institutions, started work on its new version, which was largely based on Germany's postulates (e.g., maintaining the postulated 'budget brake' and adjusting the retirement age to demographic changes). The pact was to establish stronger economic policy coordination for competitiveness and convergence. Its provisions can be considered a success of the federal government (Conclusions 11. March 2011).

According to the theoretical basis indicated earlier - the effectiveness of adaptation can only be tested in the long term by observing the response of the environment and internal structures (Simonet, 2010, p. 4). The effects of the financial crisis are still being felt, and it cannot be said that it has been resolved. However, due to the application of specific solutions and forcing its demands, the German government should be considered a key stabilizer and, despite many objections - the main steering element in a significant environment. Germany has used its economic potential to strengthen the economic governance system in the euro area. By applying specific adaptation procedures, they have gradually stabilized the situation. In this context, they played the role of a political homeostat.

The model of Germany's adaptation in case of a financial crisis should be analysed primarily from the perspective of rapid and severe external changes and a relatively stable internal situation. It does not mean, however, that the crisis has not affected the German economy. The most serious internal change was the increase in the budget deficit from 11.8 in 2008 to 49.0 in 2009 and EUR 80.2 billion in 2010. Despite these negative consequences, real GDP increased by 3.6 in 2010 percent and another 3 percent in 2011. International trade was maintained at a high level, and participation in international cooperation structures strengthened Germany's position in times of crisis. In 2011, Germany was also the EU's largest net payer (Statistisches Jahrbuch, 2011, pp. 324-325). In the context of the dynamically changing situation in Greece and other countries that have been most affected by the crisis, the implications of the crisis for the German economy should be considered as within acceptable limits for maintaining basic structures and overcoming the threat of recession. Therefore, the adaptation model can be defined as deliberative or (taking into account the second of the analysed divisions) preservative and promotive. 


\subsection{Refugee crisis}

Although at first EU asylum and visa policy was not an important determinant of German European policy, after 2015, it became Germany's political priority, primarily in terms of creating the pan-European solution to the crisis. The German response to the crisis went beyond purely economic profit and loss calculations. 'It was a symbol of European policy based on values' (Böttger and Jopp, 2017, 9-10). By adopting not only European but also international responsibility for helping refugees, Germany played the role of a state involved in European processes, especially those related to crises. The most important from the perspective of political adaptation, government actions related to the response to the intensification of migration flows from 2015 were analysed. Analysis of adaptation behavior, it is important to factor significant external changes in the German environment as well as increasing internal changes that affected social, economic, and political.

Neither the financial crisis nor the response to the Ukraine crisis has mobilized German public opinion as much as the 2015 refugee crisis (Janning and Möller, 2016, 4). The success of the populist Alternative for Germany (AfD) testifies to this. It is a party which was founded based on opposition to Germany's help for Greece, but it gained high support only in 2017, when in its election program it opposed the government's migration policy, by using negative social moods that grew along with subsequent proposals of the solution of the refugee crisis. Until 2015, A. Merkel's government had far greater public legitimacy.

The Chancellor based her strategy on helping migrants on a supranational level and the need to develop joint procedures. Its direct focus on community activities and the need to adopt a Europe-wide solution corresponded to the principles adopted in the Treaty. According to the provisions of the TFEU, migration policy and its implementation 'is subject to the principle of solidarity and fair sharing of responsibility between the Member States'. The EU shares competence with Member States in shaping migration policy, including the distribution of the number of migrants legally arriving in Europe (TFEU Article 79).

After the intensification of migration flows in 2015, Germany has become the main destination for refugees coming to Europe from Middle East countries engulfed in a civil war. Only in 2015, almost 1.1 million applicants for international protection came to Germany (Engler, 2016, p. 1). The reasons for this should be sought both in the internal structural conditions of Germany (high level of prosperity; developed social policy; the presence of immigrant communities in Germany) and in the actions of the government of A. Merkel, who in August 2015 
in the face of the deepening crisis expressed the readiness to open borders for applicants for international protection. Willkommenskultur policy as a reaction to violent external changes became the essence of political adaptation at that time. However, Germany's adaptability in this crisis proved to be ineffective. Several factors contributed to this: (1) the EU's system of managing migratory flows was not effective enough, which aggravated the crisis; (2) Germany's actions were contrary to the interests of other Member States, which reinforced the political split in the EU; (3) the possibilities of absorbing such a large number of immigrants were limited, which led to an increase in anti-immigrant sentiment and an increase in support for the AfD party, which in 2017 became the third political force in the country; (4) integration policy proved ineffective, requiring a multiannual funding framework and developing programs to adapt refugees to the labour market.

A. Merkel, based on the abovementioned pan-European solution, pushed for the relocation program on the assumption of fixed amounts of refugees accepted by each Member State. Germany's actions, however, met with great criticism. Both from conservative parties and from countries that did not agree to the suggested numbers of refugees taking into account the security of their citizens.

Another crucial issue in the aspect of actions aimed at maintaining internal socio-economic structures within acceptable limits was the improvement of asylum and integration policy. These actions can be considered as the next stage of political adaptation to the changes resulting from the crisis. In 2015-2016 two asylum packages were launched. The first was to implement instruments accelerating the asylum procedure and integrate (at an early stage) refugees who were to remain in Germany. The second asylum package, which came into force in mid-March 2016, was intended to secure the German asylum system against potential abuses and facilitate deportation procedures. Their goal was to permanently reduce the number of immigrants, especially from countries considered safe (Engler, 2016, pp. 5-6). The process of modernizing asylum policy in Germany has not been completed. In June 2019, new decisions about improving deportation arrest and limit the benefits for asylum seekers were made.

The solutions adopted by A. Merkel's government in subsequent stages of the refugee crisis resulted from adopting the model of 'convulsive' policy as an adaptation strategy, which was determined by major changes in both environments. National decision-making centers had not only to meet the expectations of a rapidly changing external environment but also to take action in response to internal pressures and social demands. Therefore, the Open-door strategy was initially 
adopted, but in the face of internal pressures, asylum packages were established to tighten migration rights and increase the rate of deportations under orderly return. The strategy of political adaptation during the height of the migration crisis was not effective. Basic internal structures were not kept within acceptable limits. Adaptive behavior influenced the structure of German society, led to changes in the German political scene, divided the Member States, and undermined the position of A. Merkel's government. Also, they weakened Germany's image as a Community leader and upset the balance in a significant environment.

\section{Conclusion}

Political adaptation of states in a regional or international dimension depends on the state's priorities and capabilities as well as conditions and absorption capacity of the external environment. Changes in this environment force a change in adaptive behavior. This process manifests itself by adopting a different strategy for conducting foreign policy or making ad hoc decisions as adequate responses to changes. The type of adaptive behavior specified in the adaptation model depends on the intensity and type of changes. However, the state does not have to adapt to all external changes. Instead, it must adopt a model of adaptation to those changes that are important to its basic structures. By identifying them it is possible to designate a significant environment of the adaptation process.

Adoption by Germany of a specific model of political adaptation depended on the stage of integration, changes taking place in the Community/EU, as well as in Germany itself. European integration has been firmly anchored in the values system of united Germany, and European policy should be considered one of the most important dimensions of foreign policy. In the context of previously described adaptive behavior models, highlighted due to internal and external changes, Germany's approach can be defined as relatively habitual or deliberative. The choice of one behavioral model is not possible because the EU had to face many crises, which in the context of Germany's adaptation should be considered as rapid external changes. Those forced German decision-makers to abandon current European policy solutions (abandon the habitual model) and adopt a deliberative approach by developing new change management tools.

During the Eurozone crisis Germany used its economic potential to strengthen the economic governance in this area. The decisions of the German government included the implementation of corrective measures and anti-crisis supervision and control procedures 
described in the text. Germany implemented the deliberative or (taking into account the second of the analyzed divisions) conservative-promotional model of adaptation and played the role of a political homeostat. A problematic issue is the refugee crisis, which caused major changes in the EU environment and relatively high internal changes in the German state, which was defined as the adoption of a 'convulsive' strategy. Equally justified is defined the adaptation model as preservative and promotive, which is oriented at maintaining a balance between the internal and external environment and strengthening cooperation with the external environment, and even exerting influence on the environment. Implementation of this model is possible due to Germany's economic potential, financial resources, and a key position in EU structures.

The adaptation process is not completed. It is a phenomenon that depends on changes, and these constantly occur in the EU, affecting the behavior and position of countries. The specificity of political adaptation during crises corresponded strongly to the parameters of German European policy discussed earlier, which means that the hypothesis about firmly embedding adaptive behavior in the concept of European policy is true. In the case of the financial crisis, the German environment was primarily exposed to rapid external changes, so the adaptation model was adapted to the external environment and changes taking place in other countries. The migration crisis has affected Germany's internal environment, and the effectiveness of adaptation was lower than the effectiveness of adaptation in case of financial crisis. Germany's role as a stabilizer of the EU, developed during the financial crisis, was undermined, as the solutions postulated by Germany this time led to a deepening of the political division within the EU.

\section{References}

1. AgGeStAM, L. and HYDE-PRICE, A. (2019) Learning to Lead? Germany and the Leadership Paradox in EU Foreign Policy. German Politics, 29 (1), pp. 8-24.

2. ALAS, R. and GAO, J. (2012) Crisis Management, Change Management, and Innovation Management. In: Alas, R. and Gao, J. (ed.) Crisis Management in Chinese Organizations. London: Palgrave Macmillan. pp. 74-92.

3. ALEXANDER, R. and HILDEBRAND, J. (2011) Euro-Krise: Europa brennt - und Deutsche sind an allen Fronten. Die Welt 19 June 2011. [online] Available at: https://www.welt.de/politik/deutschland/article13437978/Europa-brennt-und-Deutsche-sindan-allen-Fronten.html 
4. ASH, T. G. (1993) Im Namen Europas. Deutschland und der geteilte Kontinent. München: Hanser.

5. AYDIN, S., EMERSON, M., CLERCK-SACHSSE, J. and NOUTCHEVA, G. (2006) Just what is this 'absorption capacity' of the European Union? CEPS Policy Brief , 113, pp. 1-23. 6. BATES, D.G. (2005) Human Adaptive strategies: ecology, culture, and politics. Boston: Pearson Education.

7. BECKER, P. (2011) Die deutsche Europapolitik und die Osterweiterung der Europäischen Union, Baden-Baden: Nomos.

8. BOIN, A. and T'HART, P. (2006) The Crisis Approach. In: Rodriguez, H., Quarantelli, E. L. and Dynes, R. (ed.) Handbook of Disaster Research. New York: Springer. pp. 42-54.

9. BÖTTGER, K. and JOPP, M. (2017) Fundamentals of German European Policy. In: German European Policy Series 1. Berlin: Institut für Europäische Politik. pp. 1-11.

10. CANNON, W. B. (1932) The Wisdom of the Body. New York: W. W. Norton \& Company. 11. COHEN, W. M. and LEVINTHAL, D. A. (1990) Absorptive Capacity: A New Perspective on Learning and Innovation. Administrative Science Quarterly 35 (1), pp. 128-152.

12. COUNICL OF THE EUROPEAN UNION. (2011) Conclusion of the Heads of State or Government of the Euro Area Brussels 11 March 2011. [online] Available at: https://www.consilium.europa.eu/media/21423/20110311-conclusions-of-the-heads-of-stateor-government-of-the-euro-area-of-11-march-2011-en.pdf

13. DEUBNER, C. (2011) Der deutsche und französische Weg aus der Finanzkrise. DGAP Analyse 2, pp. 1-18. Berlin: Forschungsinstitut der Deutschen Gesellschaft für Auswärtige Politik.

14. DOPSON, S. and NEUMANN, J. E. (1998) Uncertainty, contrariness and the double-find: Middle managers' reactions to changing contracts. British Journal of Management, 9 (3), pp. $53-70$.

15. ENDERLEIN, H. (2010) Die Krise im Euro-Raum: Auslöser, Antworten,Ausblick Aus Politik und Zeitgeschichte, 43, pp. 7-12.

16. ENGLER, M. (2016) Germany in the refugee crisis - background, reactions and challenges. Warsaw: Heinrich Böll Foundation. 
17. EUROPEAN COMMISSION. (2014) Communication from the Commission to the European Parliament and the Council: A new EU Framework to strengthen the Rule of Law Brussels 11 March 2014, COM/2014/158 final.

18. FRANCO-GERMAN DECLARATION. (2010) Statement for the France-GermanyRussia Summit. Deauville 18 October 2010. [online] Available at: https://archiv.bundesregierung.de/resource/blob/656922/478604/81cb5f72d691edace00d9e33 c67c5a27/2010-10-19-erklaerung-gipfeltreffen-deauville-eng-data.pdf?download=1 19. GAEDTKE, J-C. (2009) Europäische Außenpolitik, Paderborn: Schöningh.

20. GILPIN, R. (1984) War and Change in World Politics. Cambridge: Cambridge University Press.

21. JAKUBOWICZ, A. (2002) L'adaptation psychologique. In: Encyclopaedia Universalis. Paris: Encyclopaedia Universalis.

22. JANNING, J. and MÖLLER, A. (2016) Leading from the centre: Germany's new role in Europe. ECFR Policy Brief July 2016. London: European Council on Foreign Relations.

23. KAUFFMANN, P. and UNTERWEDDE, H. (2010) Verlorene Konvergenz? Deutschland Frankreich und die Euro-Krise. Aus Politik und Zeitgeschichte, 43, pp. 13-19.

24. KEOHANE, N. (2012) Thinking about Leadership. Princeton, NJ: Princeton University Press.

25. KEßLER, U. (2010) Deutsche Europapolitik unter Helmut Kohl. Europäische Integration als „kategorischer Imperativ“? In: Müller-Brandeck-Bocquet, G., Schukraft, C. and Leuchtweis N. (ed.) Deutsche Europapolitik von Konrad Adenauer bis Angela Merkel. Wiesbaden: VS Verlag für Sozialwissenschaften. pp. 119-171.

26. Koalitionsvereinbarung zwischen der Sozialdemokratischen Partei Deutschlands und Bündnis 90/Die GRÜNEN. Bonn 20 October 1998. [online] Available at: https://www.spd.de/fileadmin/Dokumente/Beschluesse/Bundesparteitag/koalitionsvertrag_bu ndesparteitag_bonn_1998.pdf

27. KOENIG, N. (2014) 20 years 'core Europe': where do we stand and where are we heading? Berlin: Jacques Delors Institut.

28. KOSZEL, B. (2013) French-German Leadership in the European Union under the rule of Chancellor Angela Merkel. Journal of the Institute for Western Affairs, 1, pp. 115-143. 
29. KRAMP-KARRENBAUER, A. (2019) Making Europe right. Die Welt. [online] Available at: https://www.welt.de/politik/article190051703/Annegret-Kramp-Karrenbauer-MakingEurope-Right.html

30. MACRON, E. (2019) Renewing Europe. Project Syndicate. [online] Available at: https://www.project-syndicate.org/commentary/three-goals-to-guide-european-unionrenewal-by-emmanuel-macron-2019-03?barrier=accesspaylog

31. MAYR, E. (1982) The Growth of Biological Thought: Diversity, Evolution, and Inheritance. Cambridge: Harvard University Press.

32. MERKEL, A. (2006) Address by Chancellor Angela Merkel at the Reception for the Diplomatic Corps 1 February 2006. Berlin: Federal Chancellery. [online] Available at: http://www.bundesregierung.de/nn_6562/Content/EN/Artikel/2006/02/2006-02-01-annualreception-for-diplomatic-corps.html

33. MISTRAL, J. and UNTERWEDDE, H. (2010) Wirtschafts- und Finanzpolitik: Herausforderungen und Perspektiven einer deutsch-französischer Initiative. In: DeutschlandFrankreich: Fünf Visionen für Europa. Paris: Konrad Adenauer Stiftung. pp. 30-40.

34. OFFICIAL JOURNAL OF THE EUROPEAN UNION. (2012) Consolidated version of the Treaty on European Union, 26.10.2012 C 326/43.

35. RITTERSHOFER, C. (2007) Lexikon Politik, Staat, Gesellschaft. 3600 aktuelle Begriffe von Abberufung bis Zwölfmeilenzone. München: Beck im dtv.

36. ROSENAU, J. N. (1970) Foreign Policy as Adaptive Behavior. Comparative Politics, 2 (3), pp. 365-387.

37. ROSENAU, J. N. (1981) The Study of Political Adaptation. London: Pinter, and New York: Nichols.

38. ROSENAU, J. N., HERMANN, CH. F. and KEGLEY, CH. W. (1987). New Directions in the Study of Foreign Policy. Boston: Allen \& Unwin.

39. SCHMIDT, A. (2009) Die Wirtschafts- und Finanzkrise 2008/09 - Die erste Bewährungsprobe für Die Wirtschafts- und Währungsunion. Integration, 32 (4), pp. 388-397. 40. SCHMIDT, M. G. (1995) Wörterbuch zur Politik. Stuttgart: Alfred Kröner Verlag. 41. SIMONET, G. (2010) The concept of adaptation: interdisciplinary scope and involvement in climate change. S.A.P.I.EN.S. [online] Available at: http://journals.openedition.org/sapiens/997 
42. STATISTISCHES BUNDESAMT. (2011) Statistisches Jahrbuch für die Bundesrepublik Deutschland mit »Internationalen Übersichten«. Wiesbaden: Statistisches Bundesamt (Federal Statistical Office).

43. STOESSINGER, J. (1991) The Anatomy of the Nation-State and the Nature of Power. In: Little, R. and Smith, S. (ed.) Perspectives on World Politics. London: Routledge. pp. 23-25. 44. TACHÉ, A. (2003) L'adaptation: un concept sociologique systémique. Paris: Harmattan. 45. WALTZ, K. (1976) Theory of International Relations. In: Greenstein, F. I. and Polsby, N. W. (ed.) Handbook of Political Science, vol. 8, International Politics. Massachusetts: AddisonWesley Publishing Company. pp. 35-37.

46. WALTZ, K. N. (1969) International Structure, National Force and the Balance of World Power. In: Bell, R., Edwards, D. V. and Wagner, R. H. (ed.) Political Power. A Reader in Theory and Research,. New York: Free Press. pp. 215-231.

47. WESSELS, W. (1997) An Ever Closer Fusion? A Dynamic Macropolitical View on Integration Processes. Journal of Common Market Studies, 5 (2), pp. 267-299.

48. WORLD BANK. (2019) World Development Indicators database 23 December 2019. [online] Available at: https://databank.worldbank.org/data/download/GDP.pdf 49. WÜSTENHAGEN, J. (2004) Zwischen Parteidoktrin und Realpolitik: die DDR und die westeuropäische Integration 1957-1989. In: Konig, M. and Schulz M. (ed.) Die Bundesrepublik Deutschland und die europäische Einigung 1949-2000: Politische Akteure, gesellschaftliche Kräfte und internationale Erfahrungen. Stuttgart: Franz Steiner Verlag. pp. 495-509. 